\title{
Evaluasi Pemberian Obat Diminazene Aceturate secara In Vivo pada Mencit (Mus musculus) yang Diinfeksi Isolat Trypanosoma evansi
}

\section{Trypanocidals Diminazene Aceturate Effectivity against Isolates of Trypanosoma evansi Propagated in Mice (Mus musculus)}

\author{
Reza Yesica ${ }^{1}$, Bambang Sutrisno ${ }^{2}$, Wisnu Nurcahy $0^{3 *}$ \\ ${ }^{1}$ Laboratorium Parasitologi Veteriner, Fakultas Kedokteran Hewan Universitas Brawijaya, Puncak Dieng \\ Eksklusif Kalisongo Kecamatan Dau Kabupaten Malang, 65151 \\ ${ }^{2}$ Departemen Patologi, Fakultas Kedokteran Hewan, Universitas Gadjah Mada, J1. Fauna 2 Karangmalang, \\ Sleman, Yogyakarta 55281 \\ ${ }^{3}$ Departemen Parasitologi, Fakultas Kedokteran Hewan, Universitas Gadjah Mada Fakultas Kedokteran \\ Hewan, Universitas Gadjah Mada, Jl. Fauna 2 Karangmalang, Sleman, Yogyakarta 55281 \\ *Corresponding author, Email: wisnunurcahyo@yahoo.com
}

Naskah diterima: 29 Januari 2019, direvisi: 13 Juli 2021, disetujui: 15 Juli 2021

\begin{abstract}
Surra's disease is caused by Trypanosoma evansi parasite has been established as one of the strategic infectious animal diseases. Drug resistance in this case is one of the major challenges in handle and control them. The aim of this study is to evaluate the provision drug resistance diminazene aceturate (Tryponil®) on Trypanosoma evansi isolate from Pemalang and Brebes Central Java province with in vivo test in mice. Total 50 mice, BALB/c strain, male, 2 months, body weight \pm 30 gram are obtained from LPPT-UGM, adapted for one week. Mice were divided into 10 groups consist of 5 each. Each mouse was infected with Trypanosoma evansi by intraperitonial route. Treatment was given when mice had reached the level of parasitemia $10^{8}-$ $10^{9}$ trypanosoma / $\mathrm{mL}$ of blood this was predicted 24 hours post-infection. The administration of the drug tryapanosidal was done intraperitonial with doses $1 \mathrm{mg} / \mathrm{kg}, 3 \mathrm{mg} / \mathrm{kg}, 5 \mathrm{mg} / \mathrm{kg}$ and $7 \mathrm{mg} / \mathrm{kg}$. Observation of parasitemia did every 2 times in one week till 60 days of observation. Parasitemia observation was performed using 3 techniques. The first method was native examination used a microscope, if the negative results would be followed by MHCT (Microhaematocrit centrifugation Technique) and BCT (Buffy Coat Technique). Data obtained from the treatment group were the level of parasitemia, the number of deaths and the number of live mice from each test dose. The results are analysed by standard logit or probit. The results of this study showed the effects of the drug Dimianzene aceturate on both isolates varied. On Brebes Isolate was effective at doses of $7 \mathrm{mg} / \mathrm{kg} \mathrm{BW}(100 \%)$ and $5 \mathrm{mg} / \mathrm{kg} \mathrm{BW}(80 \%)$, whereas in the effective dose Pemalang isolate at $3 \mathrm{mg}$ dose / $\mathrm{kg} \mathrm{BW} \mathrm{(80 \% ),} 5$ and $7 \mathrm{mg} / \mathrm{kg} \mathrm{BW}(100 \%)$. While at the lowest dose of $1 \mathrm{mg} / \mathrm{kg}$ obtained a level of effectiveness of $0 \%$ in both isolates. It could be concluded that both isolates have different pathogens and indicate resistance subpopulation to diminazene aceturate.
\end{abstract}

Keywords: diminazene aceturate; in vivo; resistance; Surra; Trypanosoma evansi

\begin{abstract}
Abstrak
Penyakit Surra disebabkan parasit Trypanosoma evansi telah ditetapkan sebagai salah satu penyakit hewan menular strategis. Resistensi obat adalah salah satu tantangan besar dalam penanganan dan pengendalian Surra. Penelitian ini bertujuan untuk mengevaluasi pemberian dan mengetahui resistensi obat diminazene aceturate (Tryponil (®) pada Trypanosoma evansi isolat Pemalang dan Brebes secara in vivo pada mencit. Mencit percobaan diperoleh dari Laboratorium Pengujian dan Penelitian Terpadu (LPPT) UGM berjumlah 50
\end{abstract}


ekor starin BALB/c. Mencit dibagi menjadi 10 kelompok terdiri dari 5 ekor perkelompok perlakuan. Setiap mencit diinfeksi $10^{5}$ Trypanosoma evansi secara intraperitonial, Pengobatan diberikan ketika mencit telah mencapai tingkat parasitemia $10^{8}-10^{9}$ trypanosoma/mL darah, Pemberian obat dilakukan secara intraperitonial dengan dosis $1 \mathrm{mg} / \mathrm{kg}, 3 \mathrm{mg} / \mathrm{kg}, 5 \mathrm{mg} / \mathrm{kg}$ dan $7 \mathrm{mg} / \mathrm{kg}$. Pengamatan parasitemia dilakukan setiap $2 \mathrm{kali}$ dalam satu minggu sampai 60 hari. Pemeriksaan parasitemia dilakukan dengan menggunakan 3 teknik. Metode pemeriksaan natif menggunakan mikroskop, apabila hasilnya negatif akan dilanjutkan dengan pemeriksaan MHCT (Microhaematocrit centrifugation Technique) dan BCT (Buffy Coat Technique). Data yang diperoleh dari kelompok perlakuan adalah tingkat parasitemia, jumlah kematian dan jumlah mencit hidup dari masingmasing dosis uji. Hasil dianalisis menggunakan standard logit atau probit analyses. Hasil penelitian selama 60 hari menunjukan efek dari Dimianzene aceturate pada kedua isolate bervariasi. Pada isolat Brebes efektif pada dosis $7 \mathrm{mg} / \mathrm{kg} \mathrm{BB}(100 \%)$ dan $5 \mathrm{mg} / \mathrm{kg} \mathrm{BB}(80 \%)$, sedangkan pada isolat pemalang efektif pada dosis $3 \mathrm{mg} / \mathrm{kg}$ BB (80\%), 5 dan $7 \mathrm{mg} / \mathrm{kg} \mathrm{BB}(100 \%)$. Sedangkan pada dosis terendah $(1 \mathrm{mg} / \mathrm{kg})$ didapatkan tingkat efektifitas $0 \%$ pada kedua isolat. Simpulan dari penelitian ini bahwa kedua isolat mempunyai patogenitas dan kepekaan yang berbeda terhadap Diminazene aceturate, serta mengindikasikan adanya sub-populasi yang mengalami resistensi terhadap obat tersebut.

Kata kunci: diminazene aceturate; in vivo; resistensi; Surra; Trypanosoma evansi

\section{Pendahuluan}

Penyakit Surra merupakan penyakit pada ternak yang disebabkan oleh protozoa Trypanosoma evansi. Spesies ini merupakan hemoparasit salivarian kelas Mastigophora dengan distribusi yang meluas di seluruh dunia dan menyerang sejumlah besar mamalia domestik serta hewan liar (Desquesnes, 2013).

Pada abad ke-19 Surra dilaporkan telah menyebar ke beberapa negara diantaranya Turkestan, Annarn Selatan, Burma, Malaysia, Filipina, Indonesia (Jawa dan Sumatra) dan di Vietnam mewabah tahun 1978-1980. Kerugian ekonomi akibat infeksi $T$. evansi sebagian besar disebabkan oleh kematian hewan ternak dan mahalnya biaya pengobatan. Kerugian ekonomis yang timbul akibat Surra di Indonesia diperkirakan sebesar US\$22,4 juta per tahun (Davison et al., 2000).

Penanganan Surra umumnya dilakukan dengan pengobatan dan kontrol terhadap vektor. Akan tetapi pengendalian Surra belum optimal dilakukan karena adanya keragaman T.evansi, khususnya yang berkaitan dengan tingkat kepekaan beberapa galur terhadap trypanosidal. Resistansi obat isolat $T$. evansi telah dilaporkan dari Afrika (El Rayah et al., 1999; Boid et al., 1989) sampai Asia Timur (Dieleman, 1986). Munculnya laporan adanya galur-galur tertentu yang resisten merupakan contoh nyata dari kasus terjadinya resistensi obat. Oleh karena itu, upaya pengembangan obat anti Trypanosoma $s p$. (trypanosidal) pada hewan merupakan suatu kebutuhan.

Perkembangan obat anti trypanosoma masih statis dalam waktu lebih dari 50 tahun, sehingga muncul kasus resistensi obat yang merupakan tantangan besar dalam penanganan dan pengendalian Surra, khususnya di Asia Tenggara (Macareg et al., 2013). Kejadian resistensi obat dapat didefinisikan sebagai kemampuan strain Trypanosoma sp. yang dapat bertahan setelah pemberian obat akibat pemberian dosis yang tidak tepat (Gadir, 2007). Penelitian ini dilakukan dengan tujuan untuk evaluasi pemberian obat, efektivitas obat dan deteksi resistensi salah satu trypanosidal, terhadap dua isolat $T$. evansi yang berasal dari daerah yang berbeda dan merupakan daerah yang terdapat banyak kasus Surra, yaitu di Jawa Tengah.

\section{Materi dan Metode}

Sebanyak 50 ekor mencit strain BALB/c, berjenis kelamin jantan, berumur 8 minggu dengan berat badan kurang lebih 30gram digunakan dalam penelitian ini. Mencit diperoleh dari Laboratorium Pengujian dan Penelitian Terpadu (LPPT) UGM. Sebelum perlakuan, mencit diadaptasikan selama satu minggu dan dikelompokkan sesuai berat badan. Mencit dibagi menjadi 10 kelompok terdiri dari 
5 ekor perkelompok perlakuan dan diberi tanda pada bagian tubuhnya dengan asam pikrat. Setiap mencit diinfeksi $10^{5}$ Trypanosoma evansi secara intraperitonial (Eisler et al., 2001).

Menurut Uilenberg (1998), pengobatan diminazene aceturate (Tryponil $®$ ) dosis $1 \mathrm{mg} /$ kg pada Grup A, dosis $3 \mathrm{mg} / \mathrm{kg}$ pada Grup B, dosis $5 \mathrm{mg} / \mathrm{kg}$ pada grup C, dosis $7 \mathrm{mg} / \mathrm{kg}$ pada grup D dan distilled water pada Grup kontrol sebagai placebo, dilakukan ketika mencit telah mencapai tingkat parasitemia sebesar $4+$ atau setara dengan $10^{8}-10^{9}$ trypanosoma/ $\mathrm{mL}$ darah. Hal ini diprediksi terjadi 24 jam pasca infeksi buatan (Eisler et.al., 2001). Pemberian obat tryapanosidal dilakukan secara intraperitonial dengan dosis disesuaikan berat badan mencit dan kelompok perlakuan. Pengamatan parasitemia dilakukan setiap dua kali seminggu selama 60 hari pasca pemberian obat. Pengamatan parasitemia dilakukan dengan menggunakan 3 teknik. Pertama adalah metode pemeriksaan natif menggunakan mikroskop. Apabila diperoleh hasil negatif maka dilajutkan dengan pengamatan menggunakan MHCT (Microhaematocrit centrifugation Technique) dan BCT (Buffy Coat Technique) (OIE, 2012). Data yang diperoleh dari kelompok perlakuan adalah jumlah kematian dan mencit hidup dari masing-masing dosis uji, selanjutnya dilakukan penghitungan keberhasilan daya tripanosidal (\%). Menurut Peregine et al. (1991) dalam jurnal Eisler et al. (2001), untuk pengujian efektivitas typanosidal dengan berbagai dosis dapat dihitung menggunakan uji statistik regresi standard logit atau probit.

\section{Hasil dan Pembahasan}

Hasil penelitian selama 60 hari menunjukan bahwa obat Diminazene aceturate mempunyai efektifitas yang berbeda terhadap isolat T.evansi dari Kota Brebes dan Pemalang, Jawa Tengah. Diminazene aceturate bekerja efektif pada Isolat Pemalang dosis 5 dan $7 \mathrm{mg} / \mathrm{kg}$ BB dengan total kesembuhan $100 \%$ pada hewan coba. Sedangkan pada dosis 3 $\mathrm{mg} / \mathrm{kg}$ BB total kesembuhan sebesar $80 \%$, namun pada dosis $1 \mathrm{mg} / \mathrm{kg}$ BB total kesembuhan sebesar $0 \%$. Pada isolat Brebes Diminazene aceturate efektif $100 \%$ hanya pada dosis $7 \mathrm{mg} / \mathrm{kg} \mathrm{BB}$, sedangkan pada dosis $5 \mathrm{mg} / \mathrm{kg}$ BB terjadi kesembuhan sebesar $80 \%$. Namun, dosis 1 dan $3 \mathrm{mg} / \mathrm{kg}$ BB tidak menimbulkan kesembuhan mencit ( $0 \%)$.

Dosis yang paling tinggi $7 \mathrm{mg} / \mathrm{kg}$ BB bersifat kuratif untuk kedua isolat. Efek keempat

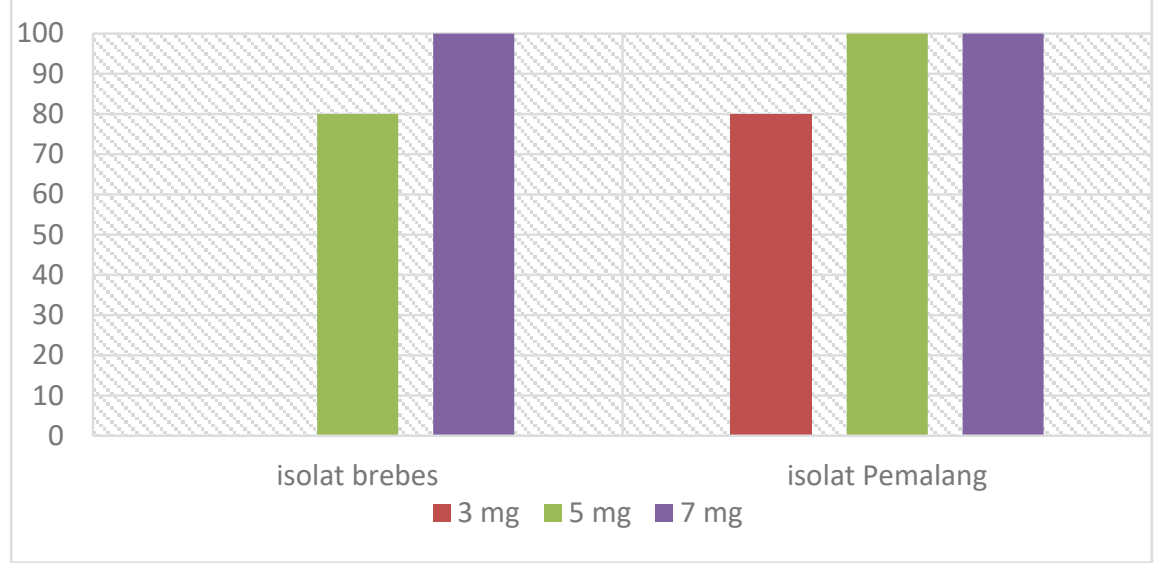

Gambar 1. Total Kesembuhan hewan coba mencit terhadap obat diminazene aceturate dengan dosis 3,5 dan $7 \mathrm{mg} / \mathrm{kg} \mathrm{BB}$.

Tabel 1. Efektivitas diminazene aceturate terhadap kedua isolat T.evansi.

\begin{tabular}{llll}
\hline Trypanosidal & Dosis $(\mathrm{mg} / \mathrm{kg})$ & Isolat Brebes & Isolat Pemalang \\
\hline Diminazene aceturate & 1 & Tidak Efektif $(0 \%)$ & Tidak efektif $(0 \%)$ \\
& 3 & Tidak efektif $(0 \%)$ & Efektif $(80 \%)$ \\
& 5 & Efektif $(80 \%)$ & Efektif $(100 \%)$ \\
& 7 & Efektif $(100 \%)$ & Efektif $(100 \%)$ \\
\hline
\end{tabular}


dosis obat diminazene aceturate pada kedua isolat T.evansi dapat ditunjukkan pada Gambar 1.

Sebanyak 5 ekor mencit (100\%) diinfeksi isolat Brebes yang diterapi dengan diminazene aceturate dosis 1 dan $3 \mathrm{mg} / \mathrm{kg}$ BB mengalami relapse. Hal ini terjadi pada minggu pertama dan kedua setelah terapi. Namun, pada dosis $5 \mathrm{mg} /$ $\mathrm{kg} \mathrm{BB}$, relapse terjadi pada 1 ekor mencit (20\%) pada minggu ketiga. Sedangkan, pada mencit yang diinfeksi isolat Pemalang mengalami relapse sebesar $100 \%$ pada dosis $1 \mathrm{mg} / \mathrm{kg}$ BB dan $20 \%$ pada dosis $3 \mathrm{mg} / \mathrm{kgBB}$ yang terjadi pada minggu ketiga (Tabel 2).

Dari analisis menggunakan logit dan probit, menunjukkan bahwa dosis obat pada isolat Brebes mempengaruhi tingkat kehidupan mencit yang diberi perlakuan injeksi T.evansi $(\mathrm{P} \leq 0,05)$. Berbeda dengan isolate Pemalang yang menunjukkan hasil yang tidak signifikan $(\mathrm{P} \geq 0,05)$. Ini berarti kedua isolat mempunyai patogenitas yang berbeda atau mengindikasikan bahwa ada sub-populasi yang mengalami resistensi terhadap diminazene aceturate.

Banyak laporan kejadian resistensi obat pada penggunaan Diminazene acetuarate di lapangan pada spesies Trypanosoma sp. yang berbeda (Luscher et al., 2006). Diminazene aceturate relatif murah, banyak tersedia dan aktif melawan trypanosomiasis serta berbagai tickborne disease termasuk babesiosis (Bruning,
1996). Keuntungan ini sering menjadikannya sebagai pengobatan pilihan pertama untuk ternak yang sakit dan penggunaan dosis yang tidak tepat dilapangan ini mungkin telah berkontribusi pada pengembangan resistensi.

Penelitian yang dilakukan oleh Macareg et al. (2013), metodeinfeksi mencit dengan T.evansi isolat Pulau Luzon, Visayas dan Mindanao, Filipina. Pada isolat Luzon, obat dimianzene aceturate efektif pada dosis $5 \mathrm{mg} / \mathrm{kg}$ BB $(100 \%$ mencit sembuh) dan gagal sembuh pada dosis yang lebih rendah. Isolat Visayas membutuhkan dosis $10 \mathrm{mg} / \mathrm{kg}$ BB untuk kesembuhan $100 \%$, dimana dosis 1,3 , dan $5 \mathrm{mg} / \mathrm{kg} \mathrm{BB}$ hanya menunjukkan kesembuhan sebesar $0 \%, 60 \%$ dan $80 \%$. Sedangkan pada isolat Mindanao, dosis 3 $\mathrm{mg} / \mathrm{kg}$ BB sudah bisa menyembuhkan $100 \%$ mencit yang terinfeksi, tetapi pada dosis $1 \mathrm{mg} /$ $\mathrm{kg}$ BB persentase kesembuhan hanya $20 \%$. Hasil penelitian tersebut menunjukan bahwa T.evansi Filipina dari daerah yang berbeda mempunyai perbedaan sensitifitas pada trypanosidal. Hasil yang sama ditunjukkan pada penelitian yang menggunakan isolat dari Jawa Tengah, dimana isolat Pemalang dosis 3, 5 dan $7 \mathrm{mg} / \mathrm{kg} \mathrm{BB}$ menunjukkan kesembuhan 100\%. Sedangkan pada T.evansi Isolat Brebes, obat dosis $7 \mathrm{mg} / \mathrm{kg}$ BB menujukan kesembuhan 100\%, sedangkan $5 \mathrm{mg} / \mathrm{kg}$ BB kesembuhan $80 \%$, dosis 1 dan $3 \mathrm{mg} /$ $\mathrm{kg}$ BB kesembuhan yang dicapai sebesar $0 \%$.

Tabel 2. Hasil penelitian hewan coba yang diinfeksi Trypanosoma evansi isolat Brebes dan Pemalang dan diobati dengan diminazene aceturate.

\begin{tabular}{|c|c|c|c|c|c|c|c|c|c|c|c|c|c|}
\hline \multirow[t]{2}{*}{ Kelompok } & \multicolumn{13}{|c|}{ Hari ke- } \\
\hline & 0 & 5 & 10 & 15 & 20 & 25 & 30 & 35 & 40 & 45 & 50 & 55 & 60 \\
\hline A1 & $0 / 5$ & $5 / 5$ & $0 / 0$ & $0 / 0$ & $0 / 0$ & $0 / 0$ & $0 / 0$ & $0 / 0$ & $0 / 0$ & $0 / 0$ & $0 / 0$ & $0 / 0$ & $0 / 0$ \\
\hline $\mathrm{A} 2$ & $0 / 5$ & $5 / 5$ & $0 / 0$ & $0 / 0$ & $0 / 0$ & $0 / 0$ & $0 / 0$ & $0 / 0$ & $0 / 0$ & $0 / 0$ & $0 / 0$ & $0 / 0$ & $0 / 0$ \\
\hline B1 & $0 / 5$ & $5 / 5$ & $0 / 0$ & $0 / 0$ & $0 / 0$ & $0 / 0$ & $0 / 0$ & $0 / 0$ & $0 / 0$ & $0 / 0$ & $0 / 0$ & $0 / 0$ & $0 / 0$ \\
\hline B2 & $0 / 5$ & $1 / 5$ & $1 / 5$ & $1 / 5$ & $0 / 4$ & $0 / 4$ & $0 / 4$ & $0 / 4$ & $0 / 4$ & $0 / 4$ & $0 / 4$ & $0 / 4$ & $0 / 4$ \\
\hline $\mathrm{C} 1$ & $0 / 5$ & $1 / 5$ & $1 / 5$ & $0 / 4$ & $0 / 4$ & $0 / 4$ & $0 / 4$ & $0 / 4$ & $0 / 4$ & $0 / 4$ & $0 / 4$ & $0 / 4$ & $0 / 4$ \\
\hline $\mathrm{C} 2$ & $0 / 5$ & $0 / 5$ & $0 / 5$ & $0 / 5$ & $0 / 5$ & $0 / 5$ & $0 / 5$ & $0 / 5$ & $0 / 5$ & $0 / 5$ & $0 / 5$ & $0 / 5$ & $0 / 5$ \\
\hline D1 & $0 / 5$ & $0 / 5$ & $0 / 5$ & $0 / 5$ & $0 / 5$ & $0 / 5$ & $0 / 5$ & $0 / 5$ & $0 / 5$ & $0 / 5$ & $0 / 5$ & $0 / 5$ & $0 / 5$ \\
\hline D2 & $0 / 5$ & $0 / 5$ & $0 / 5$ & $0 / 5$ & $0 / 5$ & $0 / 5$ & $0 / 5$ & $0 / 5$ & $0 / 5$ & $0 / 5$ & $0 / 5$ & $0 / 5$ & $0 / 5$ \\
\hline K1 & $0 / 5$ & $5 / 5$ & $0 / 0$ & $0 / 0$ & $0 / 0$ & $0 / 0$ & $0 / 0$ & $0 / 0$ & $0 / 0$ & $0 / 0$ & $0 / 0$ & $0 / 0$ & $0 / 0$ \\
\hline $\mathrm{K} 2$ & $0 / 5$ & $5 / 5$ & $0 / 0$ & $0 / 0$ & $0 / 0$ & $0 / 0$ & $0 / 0$ & $0 / 0$ & $0 / 0$ & $0 / 0$ & $0 / 0$ & $0 / 0$ & $0 / 0$ \\
\hline
\end{tabular}

Keterangan: Grup A1: Infeksi T.evansi isolat Brebes dosis terapi $1 \mathrm{mg} / \mathrm{kg} \mathrm{BB}$, Grup A2 : Infeksi T.evansi isolat Pemalang, dosis terapi $1 \mathrm{mg} / \mathrm{kg} \mathrm{BB}$, Grup B1: Infeksi T.evansi isolat Brebes dosis terapi $3 \mathrm{mg} / \mathrm{kg}$ BB, Grup B2: Infeksi T.evansi isolat Pemalang, dosis terapi 3mg/kg BB, Grup C1: Infeksi T.evansi isolat Brebes dosis terapi $5 \mathrm{mg} / \mathrm{kg} \mathrm{BB}$, Grup B2 : Infeksi T.evansi isolat Pemalang, dosis terapi $5 \mathrm{mg} / \mathrm{kg} \mathrm{BB}$, Grup D1: Infeksi T.evansi isolat Brebes dosis terapi $7 \mathrm{mg} / \mathrm{kg} \mathrm{BB}$, Grup D2: Infeksi T.evansi isolat Pemalang dosis terapi $7 \mathrm{mg} / \mathrm{kg} \mathrm{BB}$, Grup K1: Infeksi T.evansi isolat Brebes dan distilled water, Grup K2: Infeksi T.evansi isolat Pemalang dan distilled water. 
Subekti et al. (2015), dalam penelitian menunjukkan bahwa penggunaan diminazene aceturate hanya efektif pada dosis $7 \mathrm{mg} / \mathrm{kg}$ $\mathrm{BB}$, sedangkan pada dosis $3 \mathrm{mg} / \mathrm{kg} \mathrm{BB}$ hanya $16,67 \%$ yang sembuh. Hasil menujukkan bahwa hewan coba yang diobati dengan obat ini mengalami kematian lebih tinggi dari pada surramin atau melasormine dihydrochloride. Pemberian diminazene aceturate dengan dosis dibawah 5 adalah tidak tepat, karena dosis ini menunjukkan ketidakefektifan pada beberapa isolat dan dinilai terlalu rendah (Desquesnes et al., 2013). Hal ini mendukung hasil penelitian penulis, dimana isolat dari Brebes ataupun Pemalang menunjukkan hasil efektifitas obat $100 \%$ pada dosis $7 \mathrm{mg} / \mathrm{kg}$ BB tanpa menimbulkan efek toksik, namun gagal sembuh dengan dosis dibawah $5 \mathrm{mg} / \mathrm{kg}$ BB.

Penelitian di Balai Penelitian Veteriner (Balitvet) menunjukkan hampir semua isolat T. evansi yang ada di Balitvet resisten terhadap isometamidium dan sebagian terhadap diminazen aceturate (Sukanto et al., 1988). Di
Afrika, diminazene aceturate sudah lebih dari setengah abad dinyatakan sebagai obat yang resisten terhadap trypanosoma. Beberapa isolat Trypanosoma sp. membutuhkan lebih dosis lebih dari $45 \mathrm{mg} / \mathrm{kg}$ BB untuk dinyatakan sembuh. Hal ini telah mengindikasikan bahwa dibeberapa wilayah di dunia, diminazene aceturate telah mengalami resistensi (Anene et al., 2001).

Lazuardi et al. (2013), menyatakan efek obat diminazene aceturate pada T.evansi isolat Bangkalan secara in vivo pada mencit menunjukkan eliminasi parasit sebesar 50\% dapat dilakukan dengan pemberian dosis $6,858 \mathrm{mg} /$ $\mathrm{kg} \mathrm{BB}$, sedangkan eliminasi parasit sebesar $100 \%$ dengan pemberian dosis sebesar 9,138 $\mathrm{mg} / \mathrm{kg}$ BB. Hasil ini ternyata lebih besar dari pada penelitian terakhir yang dilaporkan pada tahun 2005 (5,22 mg / kg BB). Fakta tersebut menunjukkan bahwa parasit telah membentuk derivate protein permukaan baru yang mengekpresikan gen resisten tehadap diminazen. Beberapa peneliti memperkirakan bahwa variant surface glycoproteins (VSG)
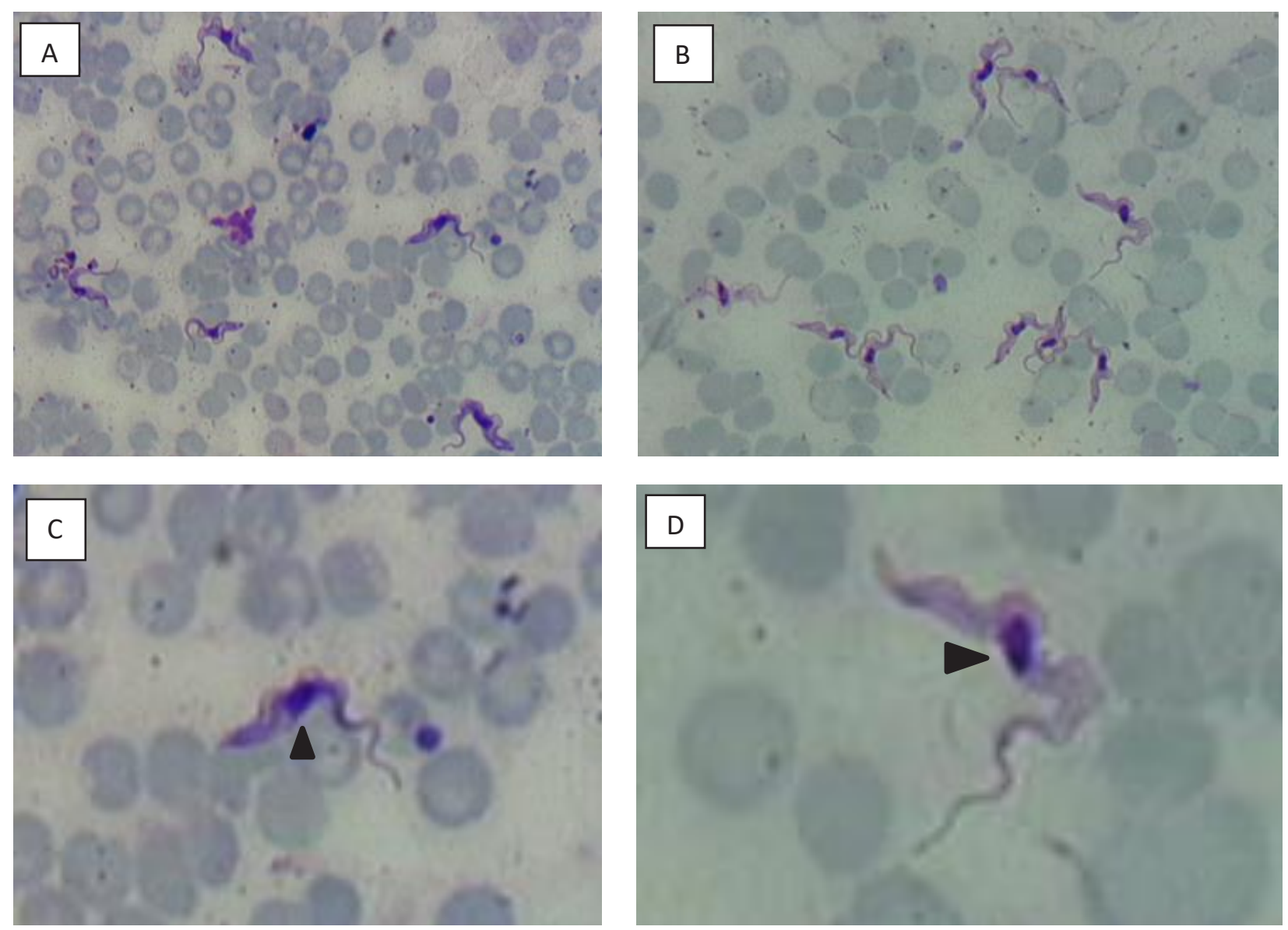

Gambar 2. Morfologi T.evansi asal Brebes (A dan C) dan Pemalang (B dan D) pada mencit kontrol hari ke-3 pasca infeksi. ( nucleus). Giemsa Stain. Mikroskop Perbesaran 1000x (Dokumentasi Penelitian) 
membuat struktur baru antigen permukaan sebagai mekanisme pertahanan parasit dengan menghasilkan salinan antigen protein setelah pemaparan lebih dari satu kemotrypanosidal atau setelah terpapar zat kemotrypanosidal lainnya.

Penelitian menggunakan isolat T. evansi dari daerah Jawa Tengah mempunyai sensitifitas yang berbeda tergantung pada keragaman yang dimiliki. Eisler et.al. (2001) menyatakan bahwa trypanosidal dikatakan efektif apabila terbukti dapat menyembuhkan $80 \%$ hewan coba. Mengacu pada ketentuan ini, dapat disusun suatu gagasan umum tentang keefektifan diminazene aceturate terhadap isolat T.evansi dari Jawa Tengah yang telah diuji, gagasan tersebut adalah dosis terbaik untuk kedua isolat dengan prosentase kesembuhan $100 \%$ adalah $7 \mathrm{mg} / \mathrm{kg} \mathrm{BB}$.

\section{Kesimpulan}

Efikasi trypanosidal ditentukan oleh kepekaan masing-masing galur $T$. evansi yang terdapat di suatu daerah serta dosis terapi yang diberikan, sehingga tidak dapat disamaratakan untuk semua kondisi. Efek dari dimianzene aceturate pada kedua isolat bervariasi. Pada isolat Brebes efektif pada dosis $7 \mathrm{mg} / \mathrm{kg}$ BB $(100 \%)$ dan $5 \mathrm{mg} / \mathrm{kg} \mathrm{BB}(80 \%)$, sedangkan pada isolat Pemalang efektif pada dosis $3 \mathrm{mg} /$ $\mathrm{kg}$ BB (80\%), 5 dan $7 \mathrm{mg} / \mathrm{kg}$ BB (100\%). Kedua isolat mempunyai patogenitas yang berbeda atau mengindikasikan bahwa ada subpopulasi yang mengalami resistensi terhadap diminazene aceturate. Dosis kuratif minimum yang ditentukan pada mencit percobaan tidak melebihi tingkat dosis yang dianjurkan pada hewan besar, yaitu $7 \mathrm{mg} / \mathrm{kg} \mathrm{BB}$.

\section{Daftar Pustaka}

Anene, B.M., Onah D.N., Nawa Y. (2001). Drug resistance in pathogenic African trypanosoma what hopes for the future? Vet Parasitol. 96: 83-10.

Boid, R., Jones, T.W., Payne, R.C. (1989). Malic enzyme type VII isoenzyme as an indicator of suramin resistance in Trypanosoma evansi. Exp. Parasitol. 69, 317-323.
Bruning, A. (1996). Equine piroplasmosis: an update on diagnosis, treatment and prevention. Br. Vet. J. 152, 139-151.

Davison, H.C., Thrusfield M.V., Husein A., Muharsini S., Partoutomo S., Rae P., Luckins A.G. (2000). The occurrence of Trypanosoma evansi in buffaloes in Indonesia, estimated using various diagnostic tests. Epidemiol Infect. 124:163-172.

Desquesnes, M., Dargantes A., Lai D.H., Lun Z.R., Holzmuller P., Jittapalapong S. (2013). Trypanosoma evansi and Surra: a review and perspectives on transmission, epidemiology and control, impact and zoonotic aspects. Biomed Res Int. 2013:120.

Eisler, M.C., Brandt J., Bauer B., Clausen P.H., Delespaux V., Holmes P.H., Ilemobade A., Machila N., Mbwambo H., McDermott J., Mehlitz D., Murilla G., Ndung'u J.M., Peregrine A.S., Sidibé I., Sinyangwe L., Geerts S. (2001). Standardised tests in mice and cattle for the detection of drug resistance in tsetse-transmitted trypanosomes of African domestic cattle. Vet Parasitol. 97:171-183.

El Rayah, I.E., Kaminsky, R., Schmid, C., El Malik, K.H. (1999). Drug resistance in Sudanese Trypanosoma evansi. Vet. Parasitol. 80, 281-287.

Gillingwater, K., Büscher P., Brun R. (2007). Establishment of a panel of reference Trypanosoma evansi and Trypanosoma equiperdum strains for drug screening. Vet Parasitol. 148:114-121.

Kroubi M, Karembe H, Betbeder D. (2011). Drug delivery systems in the treatment of African trypanosomiasis infections. Exprt Opin Drug Deliv 8(6): 735-47.

Lazuardi, M., Wahyudi M.T., Munier R.S. (2013). Re-evaluate interrelathionship dose-response of Diminazene aceturate against to infected mice of Trypanosoma evansi Bangkalan isolate. Jurnal Vteriner Juni 2013. Vol 14.No.2: 173-177.

Luscher, A. (2006) Combined contribution of TbAT1 and TbMRPA to drug resistance 
in Trypanosoma brucei. Mol. Biochem. Parasitol. 150, 364-366.

Macaraeg, B.B., Lazaro J.V., Abes N.S., Mingala C.N. (2013). Invivo assessment of the effects of trypanocidal drugs against Trypanosoma evansi isolates from Philippine water buffaloes (Bubalus bubalis). Vet Arh. 83:381392.

Nurcahyo, R. W. (2015). Pengembangan metode diagnosa molekuler Trypanosomiasis pada sapi dan kerbau sebagai upaya penanggulangan penyakit Surra di Indonesia. Laporan Kemajuan Hibah Strategi Nasional. Kementerian Riset, Teknologi dan Pendidikan Tinggi.

Office International des Epizooties. (2012). Trypanosoma evansi Infection (Surra). OIE Terrestrial Manual 2012, Chapter 2.1.17. Paris (France): Office International des Epizooties. p. 1-15.
Peregrine A.S and Mamman M. (1991). Pharmacology of diminazene aceturate: a review. Elsevier Science Publishers. 1993: 185-203.

Subekti, D.T., Yuniarto I., Sulinawati, Susiani H., Santosa B., Amaliah F., Utomo B.N., Dahlan M., Suharyanto dan Sukarya. (2015). Perbedaan Kepekaan Antar Isolat Trypanosoma Indonesia Terhadap Beberapa Trypanosidal. JITV in press.

Sukanto, I.P., Payne R.C.,Graydon R. (1988). Trypanosomiasis di Madura: Survei Parasitologik dan Serologik. Penyakit Hewan. 19(13): 14-16. 